\section{No Jobs for the Boys}

A GREAT many active researchers in the United States are still able to remember and even to recall with a mixture of bravado and nostalgia how they were first compelled to find jobs in unlikely and sometimes unsuitable occupations-schoolteaching, salesmanship or shopkeeping. In part, these hard luck stories are an illustration of how deeply the depression of the thirties left its mark on all kinds of professional people then beginning their careers ; when jobs are scarce, the newcomers inevitably find themselves at the back of the queue, with the result that whole cohorts of trained people may occasionally find themselves doing jobs for which they were not trained and which sometimes require no skill at all. But the way in which the tales of old heroism are remarked on is also a sign of the professionalization of science in the past few decades. It has now become less easy for men and women trained as scientists to earn their livings in other jobs. For one thing, training lasts so much longer that it counts as a valuable investment of time if not of money to new entrants to the labour market. Second, there is a real sense in which an interrupted career in professional science may be irreparably damaged.

The figures for unemployment in the United States now published by the National Science Foundation (see page 150) fit neatly into the pattern of employment prospects to be expected at times of economic recess. Among scientists as a whole, the rate of unemployment has increased-almost doubled-in a year but is still much better than that for the labour force as a whole $(6.5$ per cent in the first quarter of 1971). Skill is evidently an advantage still, which is borne out by the way in which people with $\mathrm{PhD}$ degrees had one of the lowest unemployment rates of all-1.4 per cent in the first quarter of the year compared with 3.5 per cent for less highly qualified scientists. Evidently one moral to be learned from this is that a person who has embarked on a career as a scientist will not benefit his employment prospects by refraining from completing a $\mathrm{PhD}$ degree.

True to the pattern of recession, the statistics also show that newly qualified people are the hardest hit, and there is nothing in the statistics to show that American employers have accepted the demands of the Women's Liberation. (In the beginning of 1971, the unemployment rate was twice as high among women scientists as among men scientists.) Predictably, many of the unemployed had been shaken out of defence and aerospace. The sobering tendency in the statistics now published is that which shows the great duration of the period of unemployment-an average of seven months by the beginning of June this year. With the next crop of graduates about to tread on the heels of those still left over from 1970, it is plain that the present recession must leave a lasting scar.

What solution can there be ? No amount of vigorous action, such as that intended by the host of bills now bemusing Congress with proposals for spending money on the retraining of scientists and engineers in the gentle causes of the fight against pollution, will make up for the interruption of young people's careers and the destruction of their expectations that the present recession has caused. Unhappily, however, it helps very little to do what the Administration has done and to argue that, if there are not enough jobs to go round, the best solution is to restrict substantially the numbers of stipends a vailable for those wishing to enter graduate schools. On the face of things, the incidence of unemployment is greatest among the age groups from 25 to 35 . Only some of these, at most a third or something like 1,000, will be people with $\mathrm{PhD}$ degrees who have left graduate schools in the sixties. Moreover, most of these are people trained in chemistry or physics - the incidence of unemployment in other fields is much more modest. Alarming though the figures may be for the individuals concerned, they are extremely small compared with the annual production of $\mathrm{PhDs}$ in the United States in recent years-18,000-odd in all the sciences and engineering in the academic year now finishing. But in any case, as the figures themselves show, a $\mathrm{PhD}$ degree is an advantage, not a handicap, in looking for a job, at least in comparison with a lesser qualification. The case for reducing the level of support for graduate schools is, in short, entirely independent of the present employment.

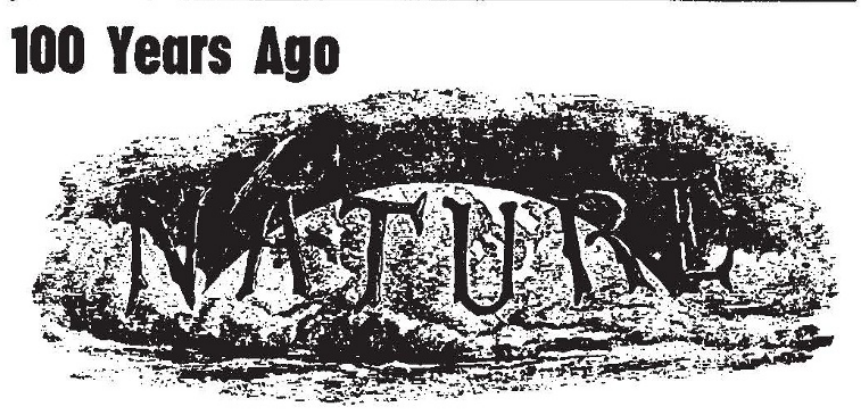

\section{LETTERS TO THE EDITOR}

[ The Editor does not hold himself responsible for opinions expressid by his Correspondents. No notice is taken of anonymous communications.]

Cotteau's "Echinides de la Sarthe"

A Notice of Cotteau et Triger's Echinides de la Sarthe in a recent number of NATURE (June 15, p. 120) is likely to convey a false impression of the accuracy of $M$. Cotteau, and throws considerable doubt on the value of his work. It is not often that French scientific men are as conscientious as he is in the examination of authentic types. There is hardly a collection of fossil Echini which M. Cotteau has not examined; and his thorough acquaintance with all that has been written on his sub ject, as well as his intimate correspondence with the principal echinologists, is a sufficient guarantee that no important memoir (such as Wright's monograph) could have escaped hiln. Anyone who will take the trouble of turning to Cotteau's work (p. I I I) will find, under Psendodiadema heinuspharicum, a notice of Dr. Wright's figure of the same species (so much superior, with many others, to Cotreau's?) and a reference to his description. Nor is this an isolated case. Throughout the work M. Cottean discusses and criticises more or less the results of this very mono. graph, said to have been overlooked by him. The mistake Cotteau is accused of making of assigning to Desor instead of Agassiz the specific name of Pseudodiadema hemispharicum is entirely unfounded. Referring again to p. ItI., we find, as a synonym Dudema hemispharicum Agass. M. Cotteau, like many continental and American writers, does not interpret the notation of species as is required by the laws of the British Association, but for that reason he should not be accused of committing mistakes which his own writings show him not to have committed. M. Cotteau, in common with others, looks upon nomenclature simply as a matter of registration; and when M. Desor transfers to Pseudodiadema the Diadema hemispharicum Agass., M. Cotteau writes, therefore, Pseudodradema hemis. phicricum Desor, and not Agassiz; he may be wrong, according to the principles of the writer in NATURE, but he has not, either in this instance or in the other cases alluded to, committed a mistake through ignorance of the subject.

A. AGiASSIZ

From Nature, 4, 220, July 20, 1871. 